
(a) Commons Attribution 40 internationel bi which allows otherwriters to use, distribute, and/or build upon this article, as long as the original work is properiy cited.

\title{
IMPLEMENTASI ASAS NEMO PLUS YURIS SEBAGAI PERLINDUNGAN HUKUM BAGI PEMEGANG HAK ATAS TANAH (STUDI KASUS PEMBATALAN SERTIFIKAT NOMOR 2690/KEBON KELAPA)
}

\author{
Naomi Elvienne Yanto \\ (Mahasiswa Magister Hukum Universitas Tarumanagara. Meraih Sarjana Hukum (S.H.) dari Universitas \\ Tarumanagara) \\ (E-mail: naomielvienne23@gmail.com) \\ Yuwono Prianto \\ (Dosen Hukum Agraria Fakultas Hukum, Universitas Tarumanagara. Meraih Sarjana Hukum (S.H) dari \\ Universitas Tarumanagara (1987), Magister Hukum (M.H.) dari Universitas Tarumanagara (2005))
}

Received: 26 Februari 2018; Accepted: 12 September 2018; Published: 19 September 2018

\begin{abstract}
:
Since act number 5 of 1960 concerning basic regulations on agrarian principles on $24^{\text {th }}$ of September 1960, it was a historic day for Indonesia. Because, that was the unification day of the land law, by revoked the land legal dualism in Indonesia for the sake to create a legal protection and also giving the legal certainty to the holders of the land rights. Likewise the act number 19 of the basic regulations on agrarian principles have instruct to held a land registration then published a land rights certificate as a proof of land ownership. It is a vigorous but not the absolute proof of land ownership, because of the impact of publication system that held in land registration in Indonesia, the land rights certificate can be canceled by a person who feels that he has rights of the land concerned. That makes the purpose of the basic agrarian principles, may not be effective due to the process of law in Indonesia concerning that basic regulations on agrarian principles concerning that it has been 58 years since the day it published.
\end{abstract}

Keywords: Legal Protection, Principles, Nemo Plus Yuris, Land Law.

\section{Pendahuluan}

\section{A. Latar Belakang}

Seperti diketahui bersama bahwa Undang-Undang Nomor 5 Tahun 1960 disahkan pada tanggal 24 September 1960 oleh Presiden Republik Indonesia Soekarno dan diundangkan dalam Lembaran Negara Republik Indonesia Nomor 104 Tahun
1960 tentang Peraturan Dasar Pokok-Pokok Agraria, yang lebih dikenal dengan nama singkatan resminya, Undang-Undang Pokok Agraria, disingkat UUPA.

Tanggal 24 September 1960 tercatat sebagai salah satu tanggal dan merupakan salah satu tonggak yang sangat penting dalam sejarah perkembangan Hukum 


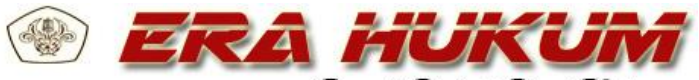 \\ Gurnal Glmiah Glmu Glukum \\ Vol. 16, No. 1, Juni 2018}

Agraria/Hukum Tanah Indonesia pada khususnya. Dengan mulai berlakunya UUPA terjadi perubahan fundamental pada Hukum Agraria di Indonesia, terutama hukum di bidang pertanahan, yang ita sebut Hukum Tanah, yang di kalangan pemerintah dan umum juga dikenal sebagai Hukum Agraria.

Perubahan itu bersifat mendasar atau fundamental, karena baik mengenai struktur perangkat hukumnya, mengenai konsepsi yang mendasarinya, maupun isinya, yang dinyatakan dalam bagian "Berpendapat" UUPA harus sesuai dengan kepentingan rakyat Indonesia serta memenuhi pula keperluannya menurut permintaan zaman. ${ }^{1}$

UUPA yang berlaku sejak tanggal 24 September 1960 telah menghapus dan mengubah sistem pertanahan pemerintah Belanda yang bersifat individualistis dengan sistem dualisme menjadi bersifat kekeluargaan berdasarkan konsep hukum adat yang menerapkan sistem unifikasi dengan kodifikasi. ${ }^{2}$ Salah satu tujuan diundangkan UUPA, adalah "meletakkan dasar-dasar untuk memberikan kepastian

${ }^{1}$ Boedi Harsono, Hukum Agraria Indonesia: Sejarah Pembentukan Undang-Undang Pokok Agraria, Isi dan Pelaksanaannya Jilid 1, (Jakarta: Penerbit Universitas Trisakti, 2013), 1.

\section{Naomi Elvienne Yanto \& Yuwono Prianto} Implementasi Asas Nemo Plus Yuris... hukum mengenai hak-hak atas tanah bagi rakyat seluruhnya". Cara untuk mewujudkan jaminan kepastian hukum mengenai hak-hak atas tanah dapat diakukan melalui pendaftaran tanah. ${ }^{3}$ Produk akhirnya adalah sertifikat yang diberikan kepada pemilik tanah, dan menjadi bukti hak terkuat atas kepemilikan tanah.

Bersamaan dengan diundangkannya UUPA, maka hak-hak atas tanah barat telah hapus, dan diganti sesuai dengan ketentuanketentuan konversi UUPA. Dengan adanya ketentuan konversi, maka masa transisi hanya berlaku sampai tanggal 24 September 1980, setelah itu semua berdasarkan Keppres Nomor 32 Tahun 1979 tentang Pokok-Pokok Kebijaksanaan dalam Rangka Pemberian Hak Baru atas Tanah Asal Konversi Hak-Hak Barat (Keppres Nomor 32 Tahun 1979). Bagi penduduk yang menguasai tanah negara bekas hak Eigendom diberikan prioritas untuk mengajukan permohonan hak atas tanah.

Eigendom juga berarti hak yang paling sempurna atas suatu benda. Seseorang yang

${ }^{2}$ Elza Syarief, Pensertifikatan Tanah Bekas Hak Eigendom, (Jakarta: Kepustakaan Populer Gramedia, 2014), vii.

${ }^{3}$ Urip Santoso, "Sertipikat Sebagai Tanda Bukti Hak atas Tanah". Jurnal Era Hukum Edisi Nomor 1/ Th. 15/ (September:2007), 67. 


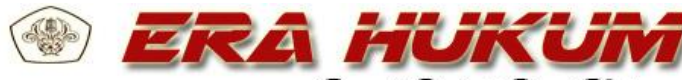 \\ Gurnal Glmiah Glmu Glukum \\ Vol. 16, No. 1, Juni 2018}

mempunyai hak Eigendom (milik) atas suatu benda dapat berbaut apa saja dengan benda itu (menjual, menggadaikan, memberikan, bahkan merusak), asal saja ia tidak melanggar undang-undang atau hak orang lain. ${ }^{4}$

Konversi adalah suatu perubahan bentuk, sifat dan nama dari sesuatu hak yang lama menjadi hak yang baru, yaitu yang diatur dalam Undang-Undang Pokok Agraria (Undang-Undang No. 5 tahun 1960 L.N. 1960 No. 104). Sebab sebelum UUPA lahir, maka berlaku "Agrarisch Wet" dan Buku II KUHPerdata dan Hukum Adat; sehingga oleh karenanya bersifat dualistis bahkan pluralistis, dan sifat inilah yang tidak dikehendaki oleh UUPA karena tujuan UUPA ingin mencapai unifikasi dalam Hukum Agraria dan adanya keseragaman atas Hak-hak tanah, maka untuk keseragaman inilah ditempuh dengan jalan Konversi. Dapat dikemukakan, bahwa Konversi dalam UUPA ini adalah alat untuk mencapai keseragaman hak-hak atas tanah menurut UUPA. ${ }^{5}$

Berkenaan dengan diterbitkannya Keputusan Presiden Nomor 32 Tahun 1979

\footnotetext{
${ }^{4}$ Subekti. Pokok-pokok Hukum Perdata. (Jakarta: PT Intermasa, 1984).69.

${ }^{5}$ R. Atang Ranoemihardja. Perkembangan Hukum Agraria di Indonesia Aspek-Aspek dalam Pelaksanaan UUPA dan Peraturan Perundangan
}

\section{Naomi Elvienne Yanto \& Yuwono Prianto} Implementasi Asas Nemo Plus Yuris...

dan Pasal 14 Undang-Undang Nomor 14 Tahun 1970 tentang Ketentuan-ketentuan Pokok Kekuasaan Kehakiman (UU Kehakiman) terkait stelsel negatif yang dalam penyelenggaraan pendaftaran tanah serta hukum acara perdata yang menerapkan pembuktian formal, telah timbul peluang bagi spekulan dan mafia tanah untuk merekayasa kepemilikan tanah yang menimbulkan sengketa tanah yang berkepanjangan sehingga menghambat pembangunan atas tanah tersebut. ${ }^{6}$

Hak Eigendom suatu hak barat atas Tanah Indonesia termasuk dalam hak-hak yang gugur atau dikonversi oleh UUPA, yang menentukan bahwa batas konversi adalah per 24 September 1980. Artinya, pemilik hak diberi waktu 20 tahun untuk mengurus konversi tersebut. Apabila tanah tersebut tidak dikonversi, tanah hak Eigendom menjadi tanah yang kembali dikuasai negara. $^{7}$

Sengketa kepemilikan tanah bermunculan terkait konversi hak Eigendom, terutama tanah yang sempat ditinggalkan atau ditelantarkan pemiliknya. Banyak orang berusaha mendapat atau

Lainnya Dibidang Agraria di Indonesia. (Bandung: Tarsito:1982), 17.

${ }^{6}$ Elza Syarief, Loc.Cit., viii.

${ }^{7}$ Ibid., hlm 3 . 


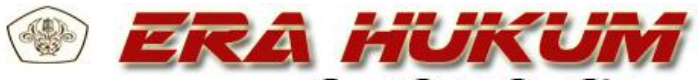 \\ Gurnal Glmiah Glmu Glukum \\ Vol. 16, No. 1, Juni 2018}

merebut pengakuan atas tanah bekas hak Eigendom entah yang telah kembali dikuasai negara atau secara de facto digarap lewat keterangan garap atas tanah atau popular dengan istilah hak atas, yang berkebalikan dengan pemegang titel Eigendom yang memegang hak bawah yang berupaya mendapat pengakuan atas tanah bekas hak Eigendom antara lain penggarap. Disini akan dipakai dua istilah: (1) penggarap murni atau mereka yang sungguh-sungguh menggarap, menguasai, dan mengelola tanah tersebut, dan (2) penggarap spekulan atau spekulan atau spekulan tanah yang berpura-pura menjadi penggarap. Seringkali terjadi pengajuan hak atas tanah yang tumpang-tindih, entah dilakukan penggarap ataupun pemilik/pemegang hak atas tanah bekas hak Eigendom. Dari sini timbul sengketasengketa tanah. ${ }^{8}$

Sengketa-sengketa tanah yang terjadi akibat konversi hak-hak atas tanah Barat antara lain adalah sertifikat hak atas tanah yang terbit akibat konversi tersebut. Sertifikat Hak atas Tanah adalah Produk Hukum yang terbit sebagai akibat diadakannya Pendaftaran Tanah. Pendaftaran tanah diselenggarakan dalam

${ }^{8}$ Ibid., hlm. 5.

\section{Naomi Elvienne Yanto \& Yuwono Prianto} Implementasi Asas Nemo Plus Yuris...

rangka memberikan jaminan kepastian hukum di bidang pertanahan. Pendaftaran Tanah di Indonesia mempunyai arti penting karena setiap orang berhak memperoleh perlindungan hukum.

Untuk memberikan perlindungan hukum diperlukan adanya kepastian hukum, sebab kepastian hukum bagi pemegang hak atas tanah mempunyai implikasi yang luas terhadap sendi-sendi kehidupan masyarakat dan negara dan oleh karena itu diperlukan suatu pemikiran objektif berdasarkan norma-norma hukum sehingga tidak berdampak negatif pada pelaksanaan pembangunan nasional. Berkenaan dengan upaya untuk memberikan jaminan kepastian hukum di bidang pertanahan yaitu kepada para pemegang hak atas tanah, penyelenggaraan pendaftaran tanah dari beberapa kalangan yaitu pemerintah dan seluruh lapisan masyarakat serta memerlukan dukungan khususnya dukungan dari pemegang hak atas tanah. Tujuan kepastian hukum dalam bidang pertanahan, khsusunya pendaftaran tanah adalah untuk memberikan perlindungan hukum bagi pemegang hak atas tanah. ${ }^{9}$

${ }^{9}$ Ibid., hlm. 16. 


\section{(40) 마영 \\ Gurnal Glmiah Glmu Glukum \\ Vol. 16, No. 1, Juni 2018}

Pada penjelasan Peraturan Pemerintah Nomor 24 tahun 1997 tentang Pendaftaran Tanah, dinyatakan bahwa sistem pendaftaran tanah di Indonesia menganut sistem negatif yang mengandung unsur positif karena akan menghasilkan suratsurat tanda bukti hak yang berlaku sebagai alat pembuktian yang kuat, seperti yang dinyatakan dalam Pasal 19 Ayat (2) huruf c, Pasal 23 Ayat (2), Pasal 32 Ayat (2) dan Pasal 38 Ayat (2) UUPA. Dengan kata lain, yaitu segala apa yang tercantum didalam sertifikat tanah dianggap benar sampai dapat dibuktikan suatu keadaan sebaliknya di muka sidang pengadilan.

Sebagai bentuk perlindungan hukum bagi pemegang hak atas tanah apabila terjadi suatu sengketa tanah, misalnya terbitnya suatu sertifikat atas nama orang yang tidak berhak, asas yang digunakan dalam hal ini adalah asas nemo plus yuris, yakni melindungi pemegang hak atas tanah yang sebenarnya dan tindakan orang lain yang mengalihkannya tanpa diketahui oleh pemegang hak sebenarnya. ${ }^{10} \mathrm{Hak}$ atas tanah adalah hak yang memberikan wewenang kepada pemegang hak atas tanah, untuk mengolah, memakai, menjual,

\footnotetext{
${ }^{10}$ Ibid., hlm. 17.

${ }^{11}$ Hanafi Tanawijaya, "Kepastian Hukum di Bidang Pertanahan dalam Rangka menunjang investasi di
}

\section{Naomi Elvienne Yanto \& Yuwono Prianto} Implementasi Asas Nemo Plus Yuris...

mengalihkan, menggunakan dan lain sebagainya di atas tanah yang di hakinya itu. $^{11}$

Kajian mengenai kekuatan berlakunya sertifikat sangat penting, setidak-tidaknya karena pertama, sertifikat memberikan kepastian hukum pemilkan tanah bagi orang yang namanya tercantum dalam sertifikat. Pernerbitan sertifikat dapat mencegah sengketa tanah. Pemilikan sertifikat akan memberikan perasaan tenang dan tentram arena dilindungi dari tindakan sewenang-wenang oleh siapa pun. Kedua, pemberian sertifikat dimaksudkan untuk mencegah kepemilikan tanah. Ketiga, dengan penerbitan sertifikat, pemilik tanah dapat melakukan perbuatan hukum apa saja sepanjang tidak bertentangan dengan undang-undang, ketertiban umum, dan kesusilaan. ${ }^{12}$

Asas nemo plus yuris artinya, tak seorangpun dapat mengalihkan hak yang lebih besar dariapada yang ia miliki. Tujuannya, melindungi pemegang hak atas tanah yang sebenarnya dari tindakan orang

Indonesia.". Buletin Ilmiah Tarumanagara, Edisi Khusus: Era Hukum, Nomor 29 (Oktober 1994). 63. ${ }^{12}$ Adrian Sutedi, Sertifikat Hak atas Tanah, (Jakarta: Sinar Grafika, 2017). 2. 


\section{(190)

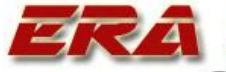 \\ Gurnal Glmiah Glmu Glukum \\ Vol. 16, No. 1, Juni 2018}

lain yang mengalihkan hal tersebut tanpa diketahui si pemegang hak sejati. ${ }^{13}$

Bukti kongkret adanya sengketa kepemilikan hak atas tanah yang ada dewasa ini terlihat dalam Putusan Nomor 487K/TUN/2016 jis. 123/B/TUN/2016, 245/G/PTUN/2015,

209/PDT/PT.DKI/2016,

59/PDT.PLW/2015 yaitu antara Santoso sebagai Pemohon Kasasi dahulu Penggugat, melawan Badan Pertanahan Nasional Kota Administrasi Jakarta Pusat sebagai Termohon Kasasi I dahulu Tergugat I dan Lim Setiawan sebagai Termohon Kasasi II dahulu Tergugat II. Bahwa yang menjadi objek gugatan adalah Sertifikat Hak Guna Bangunan Nomor 2690/Kelurahan Kebon Kelapa, Surat Ukur Nomor 00008/Kebon Kelapa/2013 tanggal 31 Januari 2013, atas Nama Pemegang Lim Setiawan, yang diterbitkan pada tanggal 2 September 2015 atas tanah seluas $751 \mathrm{~m}^{2}$ yang terletak di Jalan Batu Ceper Raya Nomor 48, Kelurahan Kebon Kelapa, Kecamatan Gambir, Kota Administrasi Jakarta Pusat yang diterbitkan oleh Tergugat, berdasarkan Surat Keputusan Kepala Kantor Pertanahan Kota Administrasi Jakarta Pusat Nomor
Naomi Elvienne Yanto \& Yuwono Prianto Implementasi Asas Nemo Plus Yuris...

928/HGB/BPN.31.71/2015;. Bersamaan dengan diterbitkannya Sertifikat Hak Guna Bangunan tersebut, adanya kepentingan Penggugat yang dirugikan sebagai pemilik sah atas tanah tersebut yang dibuktikan dengan Akta Eigendom Nomor 1104 tertanggal 14 Juli 1931 atas nama Lim Beng Giok yang merupakan ayah kandung Penggugat.

\section{B. Perumusan Masalah}

Bagaimana Penerapan Asas Nemo Plus Yuris sebagai Perlindungan Hukum bagi Pemegang Hak atas Tanah dalam Putusan Nomor Putusan Nomor 487K/TUN/2016 jis. 123/B/TUN/2016, 245/G/PTUN/2015, 209/PDT/PT.DKI/2016, 59/PDT.PLW/2015?

\section{Pembahasan}

Pada dasarnya setiap manusia terlahir sebagai makhluk ciptaan Tuhan Yang Maha Esa yang secara kodrati mendapatkan hak dasar yaitu kebebasan, hak hidup, hak untuk dilindungi, dan hak yang lainnya. Manusia memiliki akal pikiran yang membuatnya berbeda dengan mahluk ciptaan Tuhan yang lainnya. Akal ini

\footnotetext{
${ }^{13}$ Ibid., hlm. 67.
} 


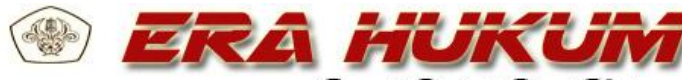 \\ Gurnal Glmiah Glmu Glukum \\ Vol. 16, No. 1, Juni 2018}

merupakan dasar dari suatu kepentingan dan tindakan yang dilakukan oleh manusia.

Hukum berfungsi sebagai pelindung kepentingan manusia dan masyarakat, dan bertujuan menciptakan ketertiban tatanan di dalam masyarakat serta bertugas mengatur hubungan antarperorangan di dalam masyarakat. ${ }^{14}$ Hukum mengatur dan mengusasai manusia dalam kehidupan bersama. Sebagai konsekuensinya, maka tata hukum bertitik tolak pada penghormatan dan perlindungan manusia. Penghormatan dan perlindungan manusia ini tidak lain merupakan pencerminan dari kepentingannya sendiri.

Jadi, hukum terdapat dalam masyarakat manusia. Pada setiap masyarakat selalu ada sistem hukum, ada masyarakat ada hukum: ubi societas ibi ius.

Menurut Sunaryati Hartono, hukum dibutuhkan untuk mereka yang lemah dan belum kuat secara sosial, ekonomi, politik untuk memperoleh keadilan sosial. Hukum tidak terlepas dari politik. Istilah politik hukum merupakan kombinasi dari politik dan hukum. Politik merupakan bidang dalam masyarakat yang berhubungan dengan tujuan masyarakat tersebut

\footnotetext{
${ }^{14}$ Sudikno Mertokusumo, Teori Hukum, (Yogyakarta: Cahaya Atma Pustaka, 2014), 44.

${ }^{15}$ Bernhard Limbong, Hukum Agraria Nasional, (Jakarta: Margaretha Pustaka, 2012). hlm 137.
}

\section{Naomi Elvienne Yanto \& Yuwono Prianto} Implementasi Asas Nemo Plus Yuris...

sekaligus aktivitas memilih suatu tujuan sosial tertentu. Persoalan serupa dihadapi hukum yakni keharusan untuk menentukan suatu pilihan mengenai tujuan maupun cara-cara yang hendak dipakai untuk mencapai tujuan tersebut. Dengan demikian, hukum tidak lagi otonom karena memiliki keterkaitan dengan sektor-sektor kehidupan dalam masyarakat. Hukum harus senantiasa melakukan penyelesaian terhadap tujuan-tujuan yang ingin dicapai oleh masyarakatnya. ${ }^{15}$

Mahfud M.D mendefinisikan politik hukum (legal policy) adalah garis (kebijakan) resmi tentang hukum yang akan diberlakukan baik dengan pembuatan hukum baru maupun dengan penggantian hukum lama, dalam rangka mencapai tujuan negara. ${ }^{16}$ Pembuatan hukum baru dan penggantian hukum lama merupakan perwujudan politik hukum.

Politik hukum agraria di Indonesia sebagai bagian politik hukum ditujukan untuk menyesuaikan hukum agraria yang berlaku dengan etik (norma kebaikan) hukum yang umum, etik hukum agraria yang khusus bagi Indonesia dan keadaan kepentingan dan kebutuhan dalam di dalam

\footnotetext{
${ }^{16}$ Mahfud M.D, Politik Hukum di Indonesia., (Jakarta: PT Raja Grafindo Persada, 2014), hlm. 1.
} 


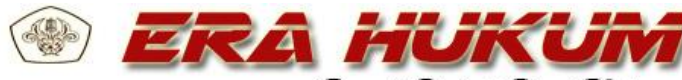 \\ Gurnal Glmiah Glmu Glukum \\ Vol. 16, No. 1, Juni 2018}

masyarakat, sehingga mempunyai corak pedagogis juga, ialah memberi petunjuk merupakan pedoman bagi perkembangan agraria untuk memperoleh pembangunan dalam lapangan agraria yang diperlukan. ${ }^{17}$

Perlindungan hukum harus melihat tahapan yakni perlindungan hukum lahir dari suatu ketentuan hukum dan segala peraturan hukum yang diberikan masyarakat yang pada dasarnya merupakan kesepakatan masyarakat untuk mengatur hubungan perilaku antara anggota-anggota masyarakat dan antara perseorangan dengan pemerintah yang dianggap mewakili kepentingan masyarakat.hukum pada jaman sekarang adalah hukum yang modern dengan ciri-ciri formal, rasional, sistematis, berlaku secara sama bagi orang, demikian hukum dijalankan oleh penegak hukum yang memang dibentuk untuk melakukan tugasnya sesuai dengan profesinya. $^{18}$

Keberadaan peraturan dalam suatu negara berdasar atas hukum (rechstaat) merupakan suatu keharusan. Hal ini karena

${ }^{17}$ Notonagoro, Politik Hukum dan Pembangunan Agraria di Indonesia, (Jakarta: Bina Aksara,1984), hlm. 1.

${ }^{18}$ Subiharta, "Moralitas Hukum dalam Hukum Praksis Sebagai Suatu Keutamaan”. Jurnal Hukum dan Peradilan, Volume 04 Nomor 3 (November:2015). 390.

\section{Naomi Elvienne Yanto \& Yuwono Prianto} Implementasi Asas Nemo Plus Yuris...

dalam negara atas hukum teradapat asas legalitas, yang berarti segala perbuatan baik bersifat kenegaraan, kebangsaan, maupun kemasyarakatan, harus berdasarkan hukum (peraturan). ${ }^{19}$

Peraturan hukum merupakan pembadanan dari norma hukum, peraturan hukum hanya merupakan salah satu saja dari lambang-lambang yang dipakai oleh norma hukum untuk membadankan dirinya. Namun bagaimanapun, peraturan hukum merupakan cara yang paling sempurna, dibanding dengan cara-cara pembadanan yang lain itu. Ia merupakan sarana yang paling lengkap untuk mengutarakan apa yang dikehendaki oleh norma hukum. ${ }^{20}$

"Hukum adalah untuk manusia dan bukan sebaliknya" merupakan kata-kata fenomenal dari pengagas hukum progresif, Prof. Satjipto Rahardjo. Beliau berpendapat bahwa hukum harus dipandang sebagai suatu alat bagi manusia untuk mencapai apa yang diharapkan dan dicita-citakan oleh manusia itu sendiri. ${ }^{21}$ Oleh karenanya, hukum harus mengandung nilai-nilai

\footnotetext{
${ }^{19}$ Rasji, "Sistem Pengaturan Negara Menurut UUD 1945". Jurnal Ilmiah Ilmu Hukum: Era Hukum Nomor 9/ Tahun 3 (Juli:1996), 17

20 Satjipto Raharjo, Ilmu Hukum, (Bandung:PT. Citra Aditya Bakti, 2014). 41.

${ }^{21}$ Muhammad Erwin. Filsafat Hukum Refleksi Kritis terhadap Hukum dan Hukum Indonesia (dalam Dimensi Ide dan Aplikasi) Edisi: Revisi. (Jakarta: PT Rajagrafindo Persada, 2011). 288.
} 


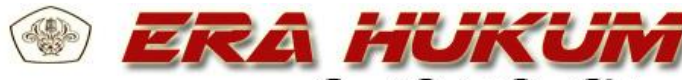 \\ Gurnal Glmiah Glmu Glukum \\ Vol. 16, No. 1, Juni 2018}

kemanusiaan dan dijalankan selaras dengan hati nurani manusia sehingga dapat memecahkan berbagai problem-problem kemanusiaan itu sendiri. Apabila tidak terjadi keselarasan antara hati nurani manusia dengan hukum, maka hukumlah yang harus diubah, bukan manusia yang dipaksa untuk menyesuaikan dengan hukum yang berlaku.

Menurut Purnadi Purbacaraka dan Soerjono Soekanto, Hukum adalah aturanaturan hidup yang terjadi karena perundang-undangan, keputusankeputusan hakim/yurisprudensi, dan kebiasaan. $^{22)}$ Disamping itu arti hukum adalah keseluruhan kumpulan peraturanperatuan atau kaidah-kaidah dalam suatu kehidupan bersama: keseluruhan peraturan tentang tingkah laku yang berlaku dalam suatu kehidupan bersama, yang dapat dipaksanakan pelaksanaanya dengan suatu sanksi. $^{23}$

Terjadinya hukum melalui pikiran yang abstrak, umum dan mendasar, yang disebut asas hukum dan yang kemudian dikonkretisasi menjadi norma atau kaidah hukum dan selanjutnya dikonkretisasi lebih lanjut menjadi peraturan hukum konkret.

\footnotetext{
${ }^{22}$ Purnadi Purbacaraka dan Soerjono Soekanto, Aneka Cara Pembedaan Hukum. (Bandung: Penerbit Alumni, 1994). 2.
}

Naomi Elvienne Yanto \& Yuwono Prianto Implementasi Asas Nemo Plus Yuris...

Meskipun asas hukum itu dikonkretisasi menjadi peraturan hukum konkret, tetapi tidak terjerumus atau larut dalam konkretisasi itu, melainkan mempertahankan "nilai tambah" dengan selalu ada dalam situasi baru yang tidak terduga tetapi dapat diharapkan. Dengan demikian, asas hukum merupakan unsur kreatif dan dinamis yang penting dalam tata hukum. ${ }^{24}$

Asas Nemo Plus Iuris Transfere (ad alium) Potest Quam Ipse Habet atau yang biasa dikenal dengan sebutan Asas Nemo Plus Yuris memiliki arti bahwa tidak ada seseorangpun yang dapat mengalihkan haknya melebihi apa yang ia haki. Terdapat dua unsur dalam rumusan ini, yaitu terhadap suatu benda kepunyaannya, seseorang tidak dapat berbuat lebih dari kewenangannya atas benda tersebut.

Asas ini dalam hukum pertanahan berfungsi untuk menjamin kepastian hukum dan memberikan perlindungan hukum bagi pemegang hak atas tanah, karena negara tidak menjamin kebenaran yang tercantum pada sertifikat hak atas tanah. Hal ini merupakan dampak dampak dari sistem publikasi negatif pada

\footnotetext{
${ }^{23}$ Sudikno Mertokusumo.Mengenal Hukum suatu Pengantar Edisi Revisi. (Yogyakarta: Cahaya Atma Pusaka, 2010)., 49.

${ }^{24}$ Sudikno Mertokusumo, Teori Hukum, Loc.cit., 46.
} 


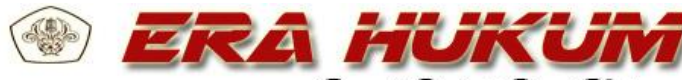 \\ Gurnal Glmiah Glmu Glukum \\ Vol. 16, No. 1, Juni 2018}

pendaftaran tanah di Indonesia. Padahal, tanah mempunyai kedudukan yang sangat sentral dan strategis bagi kehidupan manusia. Sebagaimana dibutuhkan bagi sarana dan prasarana, seperti jalan, pasar, gedung-gedung, perumahan, seperti jalan, pasar, gedung-gedung, perumahana, hingga pertahanan dan keamanan. Lain kalimat "hidup dan kehidupan manusia tidak lepas dari tanah". Setelah matipun manusia membutuhkan tanah sebagai peristirahatan terakhirnya. $^{25}$

Hak atas Tanah sebagai suatu hubungan hukum didefinisikan sebagai "hak atas permukaan bumi yang memberi wewenang kepada pemegangnya untuk menggunakan tanh yang bersangkutan, beserta tubuh bumi dan air serta ruang udara di atasnya, sekadar diperlukan untuk kepentingan yang lansung berhubungan dengan penggunaan tanah itu, dalam batasbatas menurut UUPA dan peraturan hukum yang lebih tinggi." 26

Juga, pendaftaran tanah ditujukan untuk menciptakan kepastian hukum serta perlindungan hukum bagi pemegang hak atas tanah melalui terselenggaranya pendaftaran tanah yang efektif dan

\footnotetext{
${ }^{25}$ Derta Rahmanto, "Penyelesaian Konflik dan Sengketa Sertifikat Kepemilikan Hak atas Tanah". Adil Jurnal Hukum Vol.5 Nomor 1 (Juli 2014). 42.
}

Naomi Elvienne Yanto \& Yuwono Prianto Implementasi Asas Nemo Plus Yuris...

konsisten. Sertifikat merupakan surat tanda bukti hak yang berlaku sebagai alat pembuktian yang kuat. Pernyataan tersebut pada Pasal 19 ayat (2) huruf c, menjadikan sistem publikasi di Indonesia tidak murni negatif, tetapi mengandung unsur positif. Penjelasan PP No. 24 Tahun 1997 menegaskan, bahwa sistem publikasinya adalah sistem negatif, tetapi mengandung unsur positif, karena pendaftarn tanah tersebut akan menghasilkan surat-surat tanda bukti hak yang berlaku sebagai alat pembuktian yang kuat sampai dibuktikan sebaliknya oleh pihak lain.

Asas hukum memberikan makna etis pada peraturan hukum, dalam hal adanya perlindungan yang diberikan oleh asas Nemo Plus Yuris adalah seimbang antara pemegang hak atas tanah yang sebenarnya, dengan pihak yang beriktikad baik yang telah memperoleh, menguasai, dan mendaftarkan haknya tanah. Kaidah hukum perlu juga dibedakan dari asas hukum. Sebelumnya akan dijelaskan terlebih dahulu timbulnya pasangan nilai dalam

\footnotetext{
${ }^{26}$ Maria S.W. Sumardjono. Tanah dalam Perspektif Hak Ekonomi Sosial dan Budaya. (Jakarta: Penerbit Buku Kompas, 2008).128.
} 


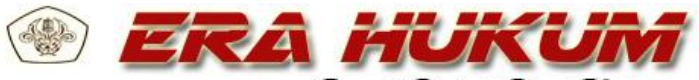 \\ Gurnal Glmiah Glmu Glukum \\ Vol. 16, No. 1, Juni 2018}

kehidupan manusia yang merupakan asal mula dari asas hukum. ${ }^{27}$

Bentuk asas hukum, adalah abstrak dan tidak dapat langsung ditemukan pada saat membaca suatu peraturan hukum. Sebagai jantung daripada norma hukum itu sendiri seperti yang dikatakan oleh Prof. Satjipto Rahardjo, asas hukum ini kemudian dikonkretisasi menjadi rumusan pasal pada peraturan perundang-undangan. Asas Nemo Plus Yuris dapat ditemukan dalam Pasal 19, 23, 32, 38 UUPA, dan Pasal, 3, 4, dan 32 ayat (2) PP No. 24 Tahun 1997.

Pada penulisan ini, akan dibahas lebih lanjut mengenai sengketa tanah yang terjadi di Jalan Batu Ceper Nomor 48 yang merupakan objek sengketa daripada putusan nomor 487K/TUN/2016 jis. 123/B/TUN/2016, 245/G/PTUN/2015, 209/PDT/PT.DKI/2016,

59/PDT.PLW/2015. Sengketa ini diawali dengan diterbitkannya Sertifikat Hak Guna Bangunan Nomor 2690/Kebon Kelapa (SHGB No. 2690/Kebon Kelapa) SHGB No. 2690/Kebon Kelapa atas nama pemegang hak Lim Setiawan yang diterbitkan pada tahun 2015 oleh Badan Pertanahan Nasional Kota Administrasi

\footnotetext{
${ }^{27}$ Soerjono Soekanto dan Sri Mamudji, Penelitian Hukum Normatif suatu Tinjauan Singkat, (Jakarta; Raja Grafindo, 2013).hlm. 62.
}

Naomi Elvienne Yanto \& Yuwono Prianto Implementasi Asas Nemo Plus Yuris...

Jakarta Pusat (BPN JAKPUS). Sertifikat ini merupakan pembaharuan hak atas exSHGB 1125/Kebon Kelapa atas nama yang sama. Sertifikat ini menjadi objek gugatan di PTUN, dengan dalil bahwa sertifikat ini telah terbit tanpa alas hak yang sah, terdapat cacat hukum pada proses penerbitannya, kemudian atas penerbitan sertifikat tersebut telah menyebabkan kerugian pada penggugat, yaitu Santoso.

Secara kronologis, Lim Setiawan mendapatkan Tanah tersebut dari Oey Josefa melalui Akta Jual Beli Nomor 34/3/1983/Gambir tanggal 29 Maret 1983 (selanjutnya disebut AJB No. 34) yang dilakukan dihadapan PPAT M.M.I Wiardi S.H., Notaris di Jakarta. Hal yang diketahui oleh Lim Setiawan sebelum transaksi jual beli tersebut adalah bahwa Oey Josefa adalah pemegang hak atas Tanah tersebut yang dibuktikan oleh ex-SHGB 1125/Kebon Kelapa.

Ex-SHGB 1125/Kebon Kelapa tersebut diterbitkan berdasarkan S.K.P.T No 4716/X/1980 bahwa tanah tersebut adalah tanah yang dikuasai langsung oleh negara, hal ini dapat dilihat dari catatan S.K.P.T yang berbunyi sebagai berikut: 


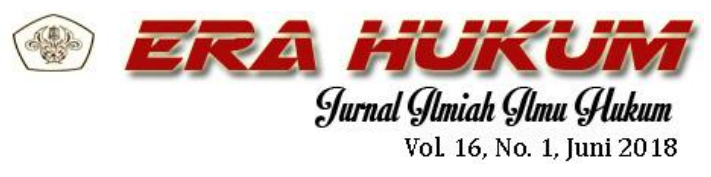

"Tanah tersebut semula adalah bekas Eig.Verp.No. 9599 surat ukur tanggal 30 Agustus 1929 No. 393 luas 892m² tertulis atas nama Lim Beng Giok, Liam Hoot Nio, Lim Ek Nio dan Lim Tek Kee yang telah berakhir haknya pada tanggal 24 September 1980 dan berdasarkan Keputusan Presiden Nomor 32 Tahun 1979, menjadi tanah yang dikuasai langsung oleh negara, yang membuka peluang bagi Oey Josefa untuk mengajukan suatu hak."

Diketahui bahwa sebelumnya Lim Beng Giok pernah mengajukan permohonan hak atas tanah a quo, pada tanggal 2 Juli 1980 kepada Kepala Kantor Agraria Kota Madya Jakarta Pusat. Kemudian dijawab dengan surantnya Nomor: 269/I/HGB/P/2/1981 tanggal 6 November 1981 yang berisikan agar Lim Beng Giok melengkapi atau memenuhi persayaratan berkas seperti Advis Planning dari Suku Dinas Tata Kota, Fotocopy IMB, Fotocopy Sertipikat/Kartu Sewa/Kartu Kaveling/Surat Penunjukan Tanah, Fotocopy Kwitansi pembayaran IPEDA tahun terakhir, Fotocopy Fatwa Waris, Surat Pernyataan Pemilikan Bangunan, Surat Pernyataan Penghuni, Surat Penetapan Hak atas Tanah yang terkena Rencana Jalan, akan tetapi selama kurang lebih satu tahun Lim Beng Giok tidak pernah dapat memenuhi persyaratan berkas tersebut.
Naomi Elvienne Yanto \& Yuwono Prianto Implementasi Asas Nemo Plus Yuris...

Mengingat Lim Beng Giok tidak pernah memenuhi persyaratan a quo, maka prioritas untuk memperoleh hak atas tanah a quo tersebut beralih kepada Penghuni sesuai dengan bunyi Pasal 13 Ayat (1) Peraturan Menteri Dalam Negeri Nomor 3 Tahun 1979 tentang Ketentuan-ketentuan Mengenai Permohonan dan Pemberian Hak Baru atas Tanah asal Konversi Hak-hak Barat (PMDN No. 3/1979) yang menyatakan sebagai berikut:

“(1) Tanah-tanah bekas Hak Guna Bangunan atau Hak Pakai asal Konversi Hak Barat yang dimaksudkan dalam Pasal 1, yang menurut peraturan perundang-undangan yang berlaku jelas tidak dapat diberikan dengan hak baru kepada pemegang haknya, sepanjang tidak diperlukan untuk proyek-proyek bagi kepentingan umum, dapat diberikan dengan sesuatu hak kepada pihak yang pada saat mulai berlakunya peraturan ini nyata-nyata menguasai dan menggunakan secara sah.”

Sehingga atas dasar PMDN No. 3/1979, surat Kepala Kantor Agraria Kota Madya Jakarta Pusat Nomor: 269/I/HGB/P/2/1981, SK Gubernur DKI Nomor 374/91/HGB/P/I/1983 dan S.K.P.T No 4716/X/1980, Oey Josefa berhak mengajukan permohonan hak baru atas Tanah bekas hak barat tersebut.

Pada pertimbangan majelis hakim mengenai dalil dari Santoso sebagai ahli 


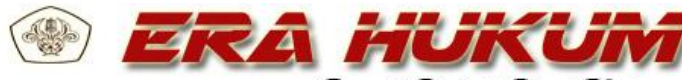 \\ Gurnal Glmiah Glmu Glukum \\ Vol. 16, No. 1, Juni 2018}

waris dari Lim Beng Giok yang mengaku sebagai pemilik yang sebenarnya atas tanah berdasarkan bukti kepemilikan Akta Eigendom 1134 adalah keliru dan tidak berdasar pada hukum positif yang berlaku. Mengingat bahwa UUPA telah menghapus dualisme hukum tanah di Indonesia dengan cara mencabutnya dan mengadakan unifikasi hukum tanah.

Mengenai konversi hak Eigendom, diatur pada diktum kedua UUPA Pasal I bahwa Hak Eigendom akan dikonversi menjadi hak milik menurut UUPA, apabila pemegang hak atas tanah tersebut memenuhi syarat pada Pasal 21 UUPA, yakni hanya orang yang berkewarganegaraan Indonesia tunggal saja, yang dapat memiliki hak milik.

Mengingat ketentuan Pasal 54 UUPA yang menyatakan:

"berhubung dengan ketentuanketentuan dalam Pasal 21 dan 26, maka jika seseorang yang di samping kewarganegaraan Indonesianya mempunyai kewarganegaraan Republik Rakyat Tiongkok telah menyatakan menolak kewarganegaraan Republik Rakyat Tiongkok itu yang disahkan menurut peraturan perundangan yang bersangkutan, ia dianggap hanya berkewarganegaraan Indoensia saja menurut Pasal 21 ayat (1)"

Bagi seseorang yang berkedwinegaraan dan memiliki hak

\section{Naomi Elvienne Yanto \& Yuwono Prianto} Implementasi Asas Nemo Plus Yuris...

Eigendom atas tanah, harus secara tegas menyatakan kewarganegaraannya dalam waktu 6 bulan sejak UUPA diundangkan (yaitu sampai dengan 24 Maret 1961) pada KKPT (Kepala Kantor Pendaftaran Tanah) apabila ia ingin mengkonversikan hak Eigendomnya tersebut menjadi hak milik.

Mengingat ketentuan mengenai orang yang memiliki dwikewarganegaraan dianggap orang asing menurut UUPA, maka pemegang hak Eigendom yang setelah jangka waktu 6 bulan lampau dan ia tidak daatang pada KKPT, atau tidak dapat membuktikan kewarganegaraannya, dicatat pada asli aktanya sebagai dikonversi menjadi hak guna bangunan dengan jangka waktu 20 tahun.

Jangka waktu 20 tahun tersebut sesuai dengan Pasal 55 Ayat (1) yang menyatakan bahwa:

"Hak-hak asing yang menurut ketentuan konversi Pasal I, II, III, IV, dan $\mathrm{V}$ dijadikan hak guna usaha dan hak guna bangunan hanya berlaku untuk sementara selama sisa waktu hak-hak tersebut, dengan jangka waktu paling lama 20 tahun."

Setahun sebelum berakhirnya jangka waktu konversi pada 1980, dalam Keppres Nomor 32 Tahun 1979 diatur bahwa tanah hak guna usaha, hak guna bangunan dan hak pakai asal konversi hak barat akan 


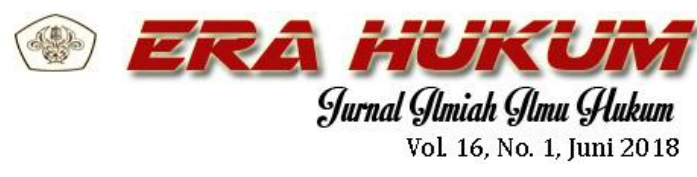

berakhir, maka pada saat haknya berakhir tanah yang bersangkutan menjadi tanah yang dikuasai oleh negara dan kepada bekas pemegang hak diberikan prioritas untuk memohon hak baru atas tanahnya, selama memenuhi syarat peraturan perundang-undangan.

Mengingat bahwa Lim Beng Giok tidak pernah menegaskan mengenai status kewarganegaraanya, ataupun mengurus kelengkapan persyaratan administrasi untuk permohonan haknya dalam jangka waktu yang telah ditentukan, maka hak Eigendom dan hak untuk mengurus tanahnya tersebut telah gugur demi hukum.

Oleh karena itu, SK Gubernur DKI Nomor 374/91/HGB/P/I/1983 dan SKPT No 4716/X/1980 menyatakan bahwa tanah tersebut adalah tanah yang dikuasai langsung oleh negara, dan atas dasar hukum tersebut BPN JAKPUS kemudian menerbitkan ex-SHGB 1125/Kebon Kelapa atas nama Oey Josefa, yang kemudian dibalik nama menjadi kepunyaan Lim Setiawan berdasarkan AJB No. 34.

Sehingga amar putusan Putusan Nomor 487 K/TUN/2016 jo. Putusan Nomor 143/B/2016/PT.TUN.JKT jo. Putusan Nomor 245/G/PTUN/2015 yang menyatakan batal Sertifikat Hak Guna Bangunan Nomor 2690/Kelurahan Kebon
Naomi Elvienne Yanto \& Yuwono Prianto Implementasi Asas Nemo Plus Yuris...

Kelapa, Surat Ukur Nomor 00008/Kebon Kelapa/2013, Nama Pemegang Hak: Lim Setiawan, yang diterbitkan pada tanggal 0209-2015, atas tanah seluas $751 \mathrm{~m}^{2}$ terletak di Jalan Batu Ceper Raya Nomor 48, Kelurahan Kebon Kelapa, Kecamatan Gambir, Kota Administrasi Jakarta Pusat yang diterbitkan oleh Tergugat, berdasarkan Surat Keputusan Kepala Kantor Pertanahan Kota Administrasi Jakarta Pusat Nomor 928/HGB/BPN $31.71 / 2015$, pada pertimbangannya majelis hakim telah keliru dalam menerapkan hukum.

Dengan demikian, gugatan atas dasar bahwa penerbitan ex-SHGB 1125/ Kebon Kelapa merupakan cacat hukum adalah suatu kekeliruan dalam membaca peraturan perundang-undangan yang berlaku.

Kesaksian Ahli dan pertimbangan hakim tersebut diatas telah keliru dalam menerapkan hukum. Menyangkut kepemilikan hak atas tanah yang berhubungan dengan Pasal 54 jo. Pasal 21 UUPA maka dibutuhkan pengesahan tertulis oleh instansi yang berwenang menyangkut kewarganegaraannya. Adalah mustahil hanya dengan datang ke BPN saja, dapat menkonversi eigendomnya menjadi hak milik. Juga UUPA telah jelas-jelas mencabut asas accessie vertikal tanah dan 


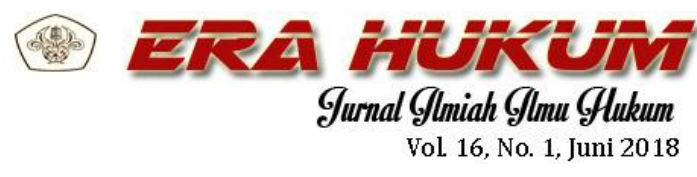

bangunan, serta ketentuan buku II KUHPer sepanjang mengenai bumi, air serta kekayaan alam yang terkandung didalamnya maka pernyataan ahli tersebut mengenai Eigendom merupakan hak milik yang bersifat mutlak menurut ketentuan Pasal 570 KUHPer yang juga berlaku sepanjang masa, adalah keliru.

Mengenai hak atas Tanah perlu dibuktikan kepemilikannya secara tertulis, apabila seseorang tidak dapat membuktikan haknya secara tertulis dalam permohonan hak baru atas Tanah asal konversi, maka berlaku Pasal 24 ayat (2) PP No. 24 Tahun 1997.

Lim Beng Giok memang pernah menyatakan keberatannya, dan memohon hak atas tanah tersebut. Akan tetapi, Lim Beng Giok tidak pernah melengkapi persyaratan-persyaratan administrasi tersebut sebagaimana telah diminta oleh Kepala Kantor Agraria Kota Madya Jakarta Pusat pada surantnya Nomor: 269/I/HGB/P/2/1981 tanggal 6 November 1981 yang berisikan agar Lim Beng Giok melengkapi atau memenuhi persayaratan berkas seperti Advis Planning dari Suku Dinas Tata Kota, Fotocopy IMB, Fotocopy Sertipikat/Kartu Sewa/Kartu Kaveling/Surat Penunjukan Tanah, Fotocopy Kwitansi pembayaran IPEDA

\section{Naomi Elvienne Yanto \& Yuwono Prianto} Implementasi Asas Nemo Plus Yuris...

tahun terakhir, Fotocopy Fatwa Waris, Surat Pernyataan Pemilikan Bangunan, Surat Pernyataan Penghuni, Surat Penetapan Hak atas Tanah yang terkena Rencana Jalan, akan tetapi selama kurang lebih satu tahun Lim Beng Giok tidak pernah dapat memenuhi persyaratan berkas tersebut.

Lim Beng Giok telah melakukan pembiaran atas Tanah tersebut dengan tidak melengkapi bukti-bukti yang diminta tersebut diatas, oleh karena itu hak atas Tanah tersebut jatuh kepada Oey Josefa sebagai pemohon hak yang menguasai secara fisik dan memenuhi persyaratanpersyaratan pada Pasal 24 ayat (2) PP No. 24 Tahun 1997 tersebut.

Sekalipun Lim Beng Giok adalah pemegang akta Eigendom 1134 atas Tanah tersebut, namun ia sudah tidak pernah menguasai lagi secara fisik tanah tersebut selama kurang lebih 58 tahun lamanya (terhitung saat Oey Josefa menempati rumah pada 1959 sebagai Penyewa sampai dengan tanah tersebut dimiliki Lim Setiawan).

Sungguhpun yang dimintakan eksekusi oleh putusan nomor 362PK/PDT/1984 adalah bangunan milik Lim Beng Giok yang kemudian tidak bisa dieksekusi karena sudah tidak ada lagi, seharusnya 


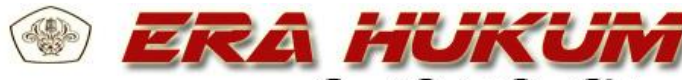 \\ Gurnal Glmiah Glmu Glukum \\ Vol. 16, No. 1, Juni 2018}

Santoso sebagai ahli waris Lim Beng Giok adalah tidak berhak untuk mengajukan eksekusi lagi atas bangunan yang sekarang milik Lim Setiawan mengingat bahwa perkara tersebut adalah antara Lim Beng Giok dan Oey Josefa. Adapun tindakan yang dapat dilakukan oleh Santoso pada perkara ini adalah meminta uang paksa kepada Oey Josefa atas eksekusi yang tidak bisa lagi dilakukan.

Dengan demikian, Putusan Nomor 209/PDT/2016/PT.DKI yang menguatkan Putusan

Nomor 59/PDT.PLW/2015/PN.JKT.PST yang pada amarnya menyatakan tidak berkekuatan hukum SK Gubernur DKI Nomor 374/91/HGB/P/I/1983 yang menjadi dasar proses penerbitan Sertipikat Hak Guna Bangunan Nomor 1125/Kebon Kelapa dengan segala akibat hukumnya serta penerbitan Sertifikat Hak Guna Bangungan Nomor 1125/Kebon Kelapa dan turutannya atas nama Nyonya Josefa Fransisca Maria Ismael, Menyatakan Batal Demi Hukum Akta Jual Beli Nomor 34/3/1983/Gambir tanggal 21 Maret 1983 serta Menyatakan Santoso adalah Pemilik yang sah atas sebidang tanah berikut segala sesuatu yang melekat diatasnya yang terletak di Jalan Batu Ceper Nomor 48, Kecamatan Gambir, Jakarta Pusat,
Naomi Elvienne Yanto \& Yuwono Prianto Implementasi Asas Nemo Plus Yuris...

berdasarkan Akta Eigendom Nomor 1104 tanggal 14 Juli 1931 adalah cacat hukum dan tidak mempunyai kekuatan hukum adalah tidak berdasar serta keliru dalam penerapan hukumnya.

Meskipun Santoso dalam hal ini adalah pemegang akta eigendom, yang merupakan pemilik atas tanah sebenarnya secara yuridis, tetapi ia telah melakukan pembiaran terhadap tanah tersebut selama kurang lebih 30 tahun sejak Lim Setiawan menempati tanah tersebut. Pembiaran dilakukan oleh Santoso tersebut serupa dengan adverse possesion yang secara tegas tidak diakui pada Hukum Tanah Indonesia, karena yang dianut hanya rechtscverwerking.

Adanya penerapan hukum oleh hakim yang tidak konsisten dengan kaidah hukum antara pembeli yang beriktikad baik dengan pemegang hak atas tanah secara yuridis. Setelah lampau 5 tahun dari penerbitan sertifikat ex-SHGB 1125/Kebon Kelapa atas nama Lim Setiawan, tidak adanya pengajuan keberatan pada BPN Jakpus.

Pada penerapannya, asas nemo plus yuris hanya akan ditemukan secara implisit pada putusan pengadilan yang memenangkan pemilik sesungguhnya (dalam hal ini pemegang akta eigendom). Seperti yang disyaratkan oleh Peraturan 


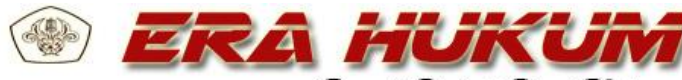 \\ Gurnal Glmiah Glmu Glukum \\ Vol. 16, No. 1, Juni 2018}

Pemerintah Nomor 24 Tahun 1997, asas

Nemo Plus Iuris tercermin dalam stelsel negatif bertendensi positif pada Pasal 32 Ayat (2). Penjelasan pasal tersebut menyatakan bahwa pihak yang namanya tercantum sebagai pemegang hak dalam buku tanah dan sertifikat, selalu menghadapi kemungkinan gugatan dari pihak lain yang merasa mempunyai tanah itu. Untuk mengatasi kelemahan stelsel negatif dalam pendaftaran tanah tersebut, diterapkanlah prinsip rechtverswerking yang mengatur bahwa pihak yang merasa mempunyai hak atas tanah/dirugikan diberikan kesempatan dalam waktu 5 (lima) tahun untuk memperjuangkan haknya.

Santoso tidak menggunakan haknya tersebut sampai dengan tahun 2015, yang berarti telah lewat dari 5 tahun sejak penerbitan sertifikat awal, yakni ex-SHGB 1125/Kebon Kelapa atas nama Oey Josefa yang kemudian dibalik nama menjadi Lim Setiawan atas dasar jual beli. Sehubungan dengan penerapan asas nemo plus yuris, jika pembeli mendapatkan suatu benda dari seseorang yang bukan pemiliknya, maka dia tak akan pernah dianggap telah memperoleh hak atas benda tersebut. Ketentuan ini pada dasarnya berlaku untuk melindungi pemilik dari tindak pencurian atau penyerobotan terhadap hak miliknya.

\section{Naomi Elvienne Yanto \& Yuwono Prianto} Implementasi Asas Nemo Plus Yuris...

Namun demikian, untuk memberikan kepastian hukum dan menjamin berlangsungnya transaksi yang sah, terdapat juga ketentuan yang melindungi posisi pembeli beritikad baik, meskipun benda itu didapatkannya bukan dari pemilik.

Lim Setiawan sebagai pihak yang membeli tanah tersebut kemudian menempatinya selama kurang lebih 30 tahun, sejak awal mengetahui dan melihat S.K.P.T yang telah diterbitkan oleh BPN Jakarta Pusat, kemudian segera setelah dilakukannya transaksi jual beli, maka Lim Setiawan meregister namanya atas tanah tersebut. Hal ini sesuai dengan sifat tanah sebagai benda tidak bergerak dan terdaftar, menjadi dasar yang mempengaruhi perlindungan hukum yang dapat diberikan bagi pembeli beritikad baik dalam jual beli tanah bersifat khusus pula, yaitu bertumpu pada informasi yang terdaftar pada register tanah - yang dapat digunakan sebagai asumsi untuk mengukur seberapa besar kemungkinan pembeli (semestinya) dapat mengetahui keabsahan pembelian yang dilakukannya.

Dari S.K.P.T tersebut diketahui bahwa tanah tersebut adalah bekas eig.verp milik Lim Beng Giok, tapi beliau telah lalai dalam melakukan penegasan konversi, 


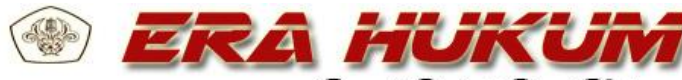 \\ Gurnal Glmiah Glmu Glukum \\ Vol. 16, No. 1, Juni 2018}

tidak mengurus tanahnya dalam jangka waktu lebih dari 30 tahun, dan melakukan pembiaran selama Lim Setiawan menempati tanah tersebut.

Apabila kita bandingkan dengan hukum Perancis, ketentuan mengenai perolehan hak dengan itikad baik ini dapat dijumpai di dalam Pasal $550 \mathrm{Cc}$, dengan rumusan sebagai berikut: "Pemegang besit adalah beritikad baik, ketika dia menguasai (suatu benda) sebagai pemilik, berdasarkan titel perolehan hak milik yang tidak dia ketahui cacat celanya. Dia tak lagi dianggap beritikad baik, pada saat cacat cela tersebut diketahuinya." Rumusan ini mengasumsikan pembeli sebagai pihak yang memperoleh (dan kemudian menguasai) suatu benda yang ternyata dia dapatkan dengan cacat cela (tidak secara sah), sementara dia tidak mengetahui adanya cacat cela itu.

Sehubungan dengan perlindungan bagi pihak yang memperoleh benda-benda terdaftar dengan itikad baik (tanpa mengetahui bahwa dia memperolehnya dari pihak yang tidak berwenang mengalihkan benda tersebut), berlaku pula Pasal 3:88 NBW. Di dalamnya disebutkan bahwa: "Meskipun pihak yang mengalihkannya tidak berwenang, suatu peralihan atas benda terdaftar, hak atas nama, atau benda

\section{Naomi Elvienne Yanto \& Yuwono Prianto} Implementasi Asas Nemo Plus Yuris...

lainnya yang tidak diatur oleh Pasal 86 adalah sah, jika pihak yang memperolehnya beritikad baik dan ketidakwenangan itu berasal dari tidak sahnya transaksi sebelumnya yang bukan merupakan akibat dari tidak berwenangnya pihak yang mengalihkan ketika itu".

\section{Penutup}

\section{A. Kesimpulan}

Berdasarkan

pembahasan permasalahan pada bab terdahulu dapat dikemukakan kesimpulan sebagai berikut:

Implementasi asas nemo plus yuris yang terdapat pada Putusan Nomor 487K/TUN/2016 jis. 123/B/TUN/2016, 245/G/PTUN/2015, 209/PDT/PT.DKI/2016, 59/PDT.PLW/2015 yang pada pokoknya membatalkan SHGB 2690/Kebon Kelapa, hanya melindungi pemilik asal. Pertimbangan majelis hakim, sama sekali tidak memperhitungkan pembeli beriktikad baik yang telah menguasai secara fisik berdasarkan tanda bukti hak berupa SHGB No. 2690/Kebon Kelapa. Terjadi kekeliruan dalam penafsiran hukumnya, karena majelis hakim luput memperhitungkan transaksi jual beli, tujuan pendaftaran tanah, serta penguasaan fisik yang dilakukan oleh Lim Setiawan dan 


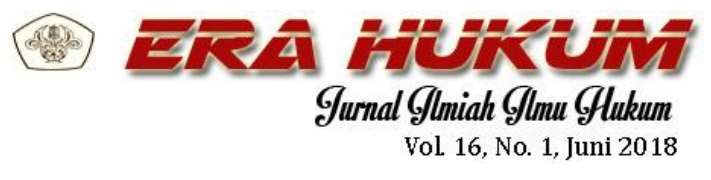

Surat Edaran Mahkamah Agung (SEMA) No. 4/2016 mengenai perlindungan kepada pembeli yang beriktikad baik.

\section{B. Saran}

Berdasarkan kesimpulan diatas, dapat dikemukakan saran sebagai berikut:

1. Perlu dilakukan perubahan pada sistem pendaftaran tanah di Indonesia yang negatif menjadi positif guna menjaminnya kepastian hukum serta memberikan perlindungan hukum bagi pemegang hak atas tanah, mengingat lembaga rechtsverwerking masih banyak kekurangan dan celah hukum untuk mengajukan keberatan terhadap sertifikat hak atas tanah.

2. Badan Pertanahan Nasional perlu melakukan maintainance lanjutan terhadap data mengenai tanah bekas hak barat hasil konversi yang langsung dikuasai oleh negara agar tidak terjadi hal-hal serupa.

3. Majelis Hakim perlu lebih konsisten dan cermat dalam menyusun ratio

\section{Naomi Elvienne Yanto \& Yuwono Prianto} Implementasi Asas Nemo Plus Yuris...

decidendi agar tercipta keseimbangan antara para pihak yang sedang bersengketa, dan tidak berhenti pada penafsiran hukum positif yang berlaku tetapi juga harus sampai kepada asas hukum yang mendasari peraturan perundang-undangan.

\section{DAFTAR PUSTAKA}

\section{A. Buku}

Erwin, Muhammad Filsafat Hukum Refleksi Kritis terhadap Hukum dan Hukum Indonesia (dalam Dimensi Ide dan Aplikasi) Edisi: Revisi. Jakarta: PT Rajagrafindo Persada, 2011.

Harsono, Boedi. Hukum Agraria Indonesia: Sejarah Pembenukan Undang-Undang Pokok Agraria, Isi dan Pelaksanaanya Jilid 1. Jakarta: Penerbit Universitas Trisakti, 2013.

Limbong, Bernhard. Hukum Agraria Nasional, Jakarta: Margaretha Pustaka, 2012.

Notonagoro. Politik Hukum dan Pembangunan Agraria di Indonesia. Jakarta: Bina Aksara,1984.

M.D, Mahfud, Politik Hukum di Indonesia, Jakarta: PT Raja Grafindo Persada, 2014. 


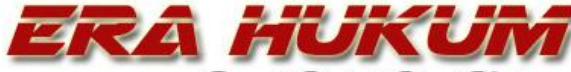 \\ Gurnal Glmiah Glmu Glukum \\ Vol. 16, No. 1, Juni 2018}

Mertokusumo, Sudikno. Teori Hukum,

Yogyakarta: Cahaya Atma

Pustaka, 2014.

Sudikno. Mengenal

Hukum Suatu Pengantar Edisi Revisi, Yogyakarta: Cahaya Atma Pustaka, 2010.

Soekanto, Soerjono dan Sri Mamudji, Penelitian Hukum Normatif suatu Tinjauan Singkat, (Jakarta; Raja Grafindo, 2013)

Subekti. Pokok-pokok Hukum Perdata. (Jakarta: PT Intermasa, 1984).

Sumardjono, Maria S.W. Kebijakan Pertanahan antara Regulasi dan Implementasi. (Jakarta: Penerbit Buku Kompas, 2006).

Sutedi, Adrian. Sertifikat Hak atas Tanah. (Jakarta: Sinar Grafika, 2017).

Syarief, Elza. Pensertifikatan Tanah Bekas Hak Eigendom. Jakarta: Kepustakaan Populer Gramedia, 2014.

Purbacaraka, Purnadi dan Soerjono Soekanto, Aneka Cara Pembedaan Hukum. (Bandung: Penerbit Alumni, 1994). Raharjo, Satjipto. Ilmu Hukum, Bandung:PT. Citra Aditya Bakti, 2014.

Ranoemihardja, R. Atang. Perkembangan Hukum Agraria di Indonesia Aspek-Aspek dalam Pelaksanaan UUPA dan Peraturan Perundangan Lainnya Dibidang Agraria di Indonesia. Bandung: Tarsito:1982.

\section{B. Jurnal}

Santoso Urip, "Sertipikat Sebagai Tanda Bukti Hak atas Tanah". Jurnal Era Hukum .Edisi Nomor 1. (September 2007): 60-77.

Subiharta, "Moralitas Hukum dalam Hukum Praksis Sebagai Suatu Keutamaan". Jurnal Hukum dan Peradilan, Volume 04. Nomor 3. (November2015): 385-398.

Rahmanto, Derta. "Penyelesaian Konflik dan Sengketa Sertifikat Kepemilikan Hak atas Tanah". Adil Jurnal Hukum Vol.5 Nomor 1 (Juli 2014): 40-52.

Rasji, "Sistem Pengaturan Negara Menurut UUD 1945". Jurnal Ilmiah Ilmu Hukum: Era Hukum Nomor 9/ Tahun 3 (Juli 1996): 1027

Tanawijaya, Hanafi "Kepastian Hukum di Bidang Pertanahan dalam Rangka menunjang investasi di Indonesia.”. Buletin Ilmiah Tarumanagara, Edisi Khusus: Era Hukum, Nomor 29 (Oktober 1994): 60-73. 